\title{
Elimination of trachoma from Morocco: a historical review
}

\author{
Jaouad Hammou, ${ }^{1,2}$ Majdouline Obtel, ${ }^{2,3}$ Rachid Razine, ${ }^{2,3}$ Amina Berraho ${ }^{4}$ and Mohamed Belmekki ${ }^{5}$
}

${ }^{1}$ Faculty of Medicine and Pharmacy of Rabat, Mohammed V University, Rabat, Morocco. ${ }^{2}$ Social Medicine Laboratory (Public Health, Hygiene and Preventive Medicine), Faculty of Medicine and Pha rmacy of Rabat, Mohammed V University, Rabat, Morocco. ${ }^{3}$ Laboratory of Biostatistics, Clinical Research and Epidemiology (LBRCE), Department of Public Health, Faculty of Medicine and Pharmacy of Rabat, Mohammed V University, Rabat, Morocco. ${ }^{4}$ Hassan II Foundation of Ophthalmology, Rabat, Morocco. ${ }^{5}$ Abulcasis International University of Health Sciences (UIASS), Rabat, Morocco. (Correspondence to: Jaouad Hammou: hjaouad2020@yahoo.fr).

\begin{abstract}
Since the 1950s, the Kingdom of Morocco has been and remains one of the pioneers in the fight against trachoma, a disease that has completely disappeared in the majority of its national territory, but some endemic pockets have persisted and pose a health risk, particularly for children and women. Morocco finds itself today, thanks to years of joint efforts, at the forefront of the world stage of the fight against trachoma. The country has demonstrated through its experience the effectiveness and relevance of the "SAFE" strategy - an extensive programme designed to tackle trachoma and its complications. The strategy is complex in its implementation and requires the synergy of a set of actors dedicated to specific activities, whether medico-surgical management activities aimed at setting up a physical project for local development, or information and awareness-raising activities. The key to the long-term success of eliminating blinding trachoma was not only to link distribution of drugs to the entire project area for several years to reduce substantially the reservoir of human-to-human transmission, but also to ensure permanence. In addition, services that provide quality palpebral surgery and especially repeat treatment campaigns with antibiotics, as well as health education campaigns and the promotion of personal and collective hygiene have generated sustainable changes in the living environment of receiving populations.

Keywords: Trachoma, Chlamydiae trachomatis, blindness, SAFE strategy, neglected tropical diseases

Citation: Hammou J; Obtel M; Razine R; Berraho A; Belmekki M. Elimination of trachoma from Morocco: a historical review. East Mediterr Health J. 2020;26(6):713-719. https://doi.org/10.26719/emhj.19.014
\end{abstract}

Received: 31/05/18; accepted: 27/02/19

Copyright (C) World Health Organization (WHO) 2020. Open Access. Some rights reserved. This work is available under the CC BY-NC-SA 3.o IGO license https://creativecommons.org/licenses/by-nc-sa/3.o/igo

\section{Introduction}

Trachoma, caused by particular serovars of Chlamydia trachomatis, is the leading infectious cause of blindness (1). Infection is associated with an inflammatory conjunctivitis known as "active trachoma". Repeated episodes (2) of active trachoma can result in eyelid scarring, which in some individuals leads to trachomatous trichiasis (TT), in which one or more eyelashes are diverted to touch the eye. TT is extremely painful (3). It can be corrected surgically. If it is left untreated, it can lead to corneal opacification, low vision and blindness.

Endemic blinding trachoma is found in populations with poor personal and community hygiene. Factors associated with elevated individual risk of trachoma include lack of adequate water supply, absence of basic sanitation facilities, living with a trachoma case, crowding and poverty in general. The common element seems to be the presence of children with dirty faces in the proximal environment: the presence of infectious ocular and nasal discharges facilitates transmission.

Trachoma can be eliminated as a public health problem using a package of interventions known as the "SAFE strategy", comprising surgery for TT, antibiotics to clear ocular C. trachomatis infection and facial cleanliness and environmental improvement (particularly improved access to water and sanitation) to reduce $C$. trachomatis transmission (4).

Worldwide, an estimated 1.9 million people are visually impaired as a result of trachoma, of whom 450 000 are blind (5). As of 2018, there were 157.7 million people living in districts in which the trachomatous inflammation-follicular (TF: the presence of five or more follicles, each at least $0.5 \mathrm{~mm}$ in diameter, in the central part of the upper tarsal conjunctiva) prevalence was $\geq 5 \%$ in 1-9-year-olds (6). In 2016, the global burden of TT was estimated to be 2.8 million cases in all endemic countries combined (7).

Morocco does not contribute people to either of these prevalence estimates, having recently been acknowledged to have eliminated the disease as a public health problem, after decades of work against the disease. Here, we set out to document the history of trachoma control in Morocco to 1) keep in memory this disease which may present a future risk of re-emergence; 2) demonstrate the relevance of the SAFE strategy as a control tool; and 3) share our experience with all endemic countries, in case the lessons we learned are also useful for them.

\section{Methods}

\section{History of the fight against trachoma in Morocco}

The first Moroccan statistics on trachoma date from 1927 to 1952, when it became clear that trachoma was prevalent throughout the country, with a greater frequency in its southern part $(8,9)$. The information for the years prior to 1952, although interesting, is some- 
what difficult to interpret epidemiologically, because often no clear distinction was made between inflammatory and cicatricial trachoma (10). In this bibliographic context, the first critical reference work remains the surveys carried out by Kupka et al. between 1962 and $1965(11,12)$ in the regions of Errachidia, Ouarzazate, Tata and Goulmima, where the active trachoma prevalence was between $85 \%$ and $99 \%$, varying between zones. The proportion of active trachoma cases to all cases ranged from $41 \%$ to $63 \%$. TT affected $2-7 \%$ of the population, and the severity of trachoma was more marked in females.

In 1952, a mass trachoma treatment programme was launched in Morocco. The campaign involved topical application of $1 \%$ chlortetracycline ointment, twice daily, for 3-5 consecutive days per month for 6 months (13). Between 1953 and 1971, Morocco, in collaboration with the World Health Organization (WHO) and the United Nations Children's Fund (UNICEF) trained doctors and nurses about trachoma at the National Center of Ophthalmology of Salé (a city near Rabat). Subsequently, teams were deployed throughout the national territory, particularly in the regions of the Draa Valley and Dades, to treat populations with trachoma $(13,14)$.

In 1954 an experiment was conducted in 24 southern Moroccan villages to provide data for an evaluation of the three fundamental measures for the control of epidemic eye infections: first, mass treatment and prevention with an antibiotic during the epidemic conjunctivitis season; secondly, mass sulfonamide treatment before the epidemic season, to reduce the frequency of human sources of contagion; and third, fly control. The main objective of the latter study was to reduce the number of fly populations in the villages and to study: 1) natural seasonal variations between different fly species; 2) the role of these species in seasonal conjunctivitis epidemics; and 3) the effect of fly control on such epidemics. This parts of the story shows how much Morocco was engaged in the fight against trachoma through diversified actions, particularly the environmental component. Through this study, a correlation was established between the number of flies and the frequency of conjunctivitis. The investigators recommended establishing a sanitation programme over the long term (15).

Kupka et al. studies during 1962-1965 investigated environmental factors, particularly water resources and their use, as well as the relationship between the prevalence and severity of trachoma in women and the increased risk of exposure to infection. There was a clear correlation between the prevalence of trachoma and the distance from housing to water supplies, the risk being higher when the distance grew. There were more cases of active (inflammatory) trachoma when use of water for hygiene was low (12) (Figure 1).

In 1975, the Morocco trachoma control strategy was revised following analysis of the epidemiological situation based on provincial reports and targeted surveys. The revision proposed a two-component

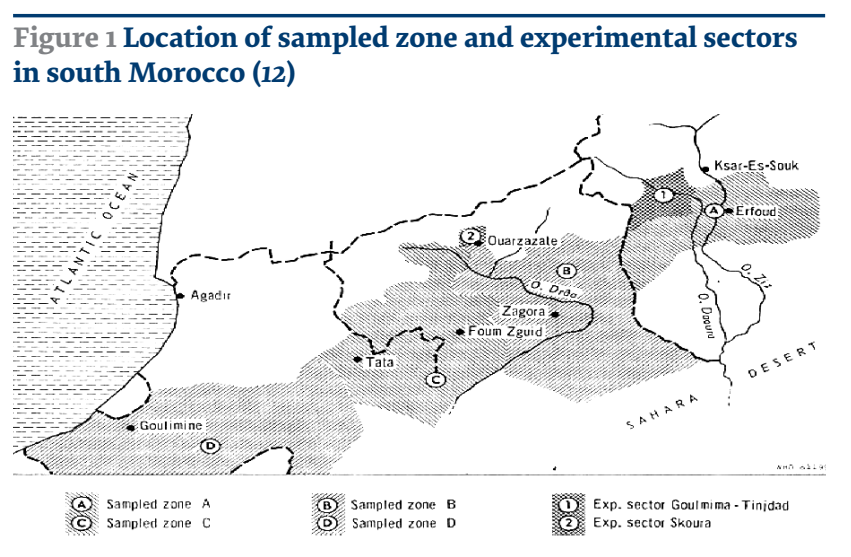

approach: 1) a school-specific strategy based on the organization of national days to fight communicable ophthalmia, which concerned all community (traditional) and primary schools. This strategy was based on the treatment of all detected cases with topical chlortetracycline $1 \%$, twice daily, for 5 days in the case of conjunctivitis, and 6 weeks in the case of active trachoma, health education also being offered (16); and 2) a strategy for the entire population in 14 provinces in the southeast of the country. These campaigns for the prevention of communicable ophthalmia were organized each year in October and November. Treatment was based on the application of chlortetracycline $1 \%$, twice daily for 3 days. If a case of active trachoma was found, the treatment involved application of chlortetracycline $1 \%$, 2 times a day for 6 weeks and treatment to all members of the family (17).

During the 1990s, epidemiological investigations confirmed the ongoing reality of trachoma in Morocco. Despite many years of specific control, the disease was still a major cause of preventable blindness. Certainly, the improvement in standards of living of the majority of the population closely correlated to the economic development experienced by the country, and had significantly reduced the geographical extent of trachoma to a point at which it had disappeared completely from Moroccan cities and most of the national territory. However, some residual provinces in the south-east of the country remained affected. This situation was confirmed in 1992 by a national survey on the prevalence and causes of blindness.

The 1992 survey estimated the overall national prevalence of trachoma to be $5.4 \%$. Virtually all cases were found in rural communities of Errachidia, Figuig, Ouarzazate, Tata and Zagora. Women and children were the most affected. Approximately 360000 people had TF or TI (trachomatous inflammation-intense: pronounced inflammatory thickening of the upper tarsal conjunctiva that obscures more than half of the normal deep tarsal vessels), while TT affected between 35000 and 40000 people (18). The national survey thus made it possible to establish a national report card on trachoma, with identification of the remaining endemic areas. 
To know more about the epidemiological situation, the Ministry of Health organized further studies. In 1992, a survey was conducted in the province of Ouarzazate to: 1) assess the magnitude and severity of disease; and 2) train health workers on the epidemiological evaluation of trachoma, including the use of the simplified trachoma grading system recommended by WHO (19).

The study was conducted in conformity with the guidelines proposed by WHO, with a random sample of 30 clusters selected from the general population of the province, using a probability proportional to size method. Thus, the sample comprised 1200 individuals, of whom 1185 were examined. The overall prevalence of active trachoma (TF and/or $\mathrm{TI}$ ) was $18 \%(95 \% \mathrm{CI}=12.8-23.2 \%)$. The prevalence of TI in children aged under 10 years was $12.8 \%$ (95\% CI $=6.8-18.8 \%$ ). The severity of disease was confirmed by a prevalence of TT of $2.2 \%$ ( $95 \% \mathrm{CI}=$ $1.4-3.0 \%$ ) and of corneal blindness, which was estimated at $1.6 \%$. After this study, the investigators concluded that trachoma deserved public health attention, particularly in the valley of Oued Draa, where all the indicators suggested more severe disease than that found elsewhere in the province (20).

In 1993, the Ministry of Health conducted a new survey on the prevalence and severity of trachoma in the target provinces. The blinding character of trachoma was again demonstrated: TT affected $1 \%$ and $2.2 \%$ of $>15$-yearolds in Figuig and Ouarzazate, respectively, while corneal opacities were estimated to affect $1.2 \%$ and $3.3 \%$ of $>15$-year-olds in those two provinces (21).

In 1998, the World Health Assembly adopted resolution WHA51.11 on the global elimination of blinding trachoma. It recommended increased implementation of the SAFE strategy (22). In 1999, Morocco and four other trachoma-endemic countries (Ghana, Mali, the United Republic of Tanzania and Viet Nam) were offered the support of the International Trachoma Initiative (ITI) to fight the disease even more effectively, with launch of a range of intersectoral activities. The five countries incorporated an azithromycin mass-drug administration programme into their therapeutic strategy.

Thereafter, the SAFE strategy was introduced in the target provinces of Morroco (Errachidia, Figuig, Ouarzazate, Tata and Zagora). Many actions were undertaken. Several thousand cases of TT were operated annually by trained health workers. Active trachoma was addressed through mass treatment with azithromycin plus implementation of the $\mathrm{F}$ and E components of SAFE in collaboration with national partners, including the Ministry of National Education, the Ministry of Employment, Social Development and Solidarity, the Ministry of Equipment, the National Office of Drinking Water, Helen Keller International Morocco, Hassan II Ophthalmology Foundation and local development associations.

The use of azithromycin was first tested in the province of Tata before being generalized in 1999 to the other four provinces. Approximately 700 ooo doses of this drug were distributed annually between 1999 and 2005 (23). This achieved antibiotic coverage of $\geq 80 \%$ of the eligible population in the targeted provinces and (in concert with the $\mathrm{F}$ and $\mathrm{E}$ activities) a reduction in prevalence of active trachoma among children aged 1-9 years to $\leq 5 \%$ (Figure 2 ).

Figure 2 Prevalence of trachomatous inflammation-follicular (TF) in children aged 1-9 years, by province, Morocco 1997, 1999, 2001, 2003, 2004 and 2005

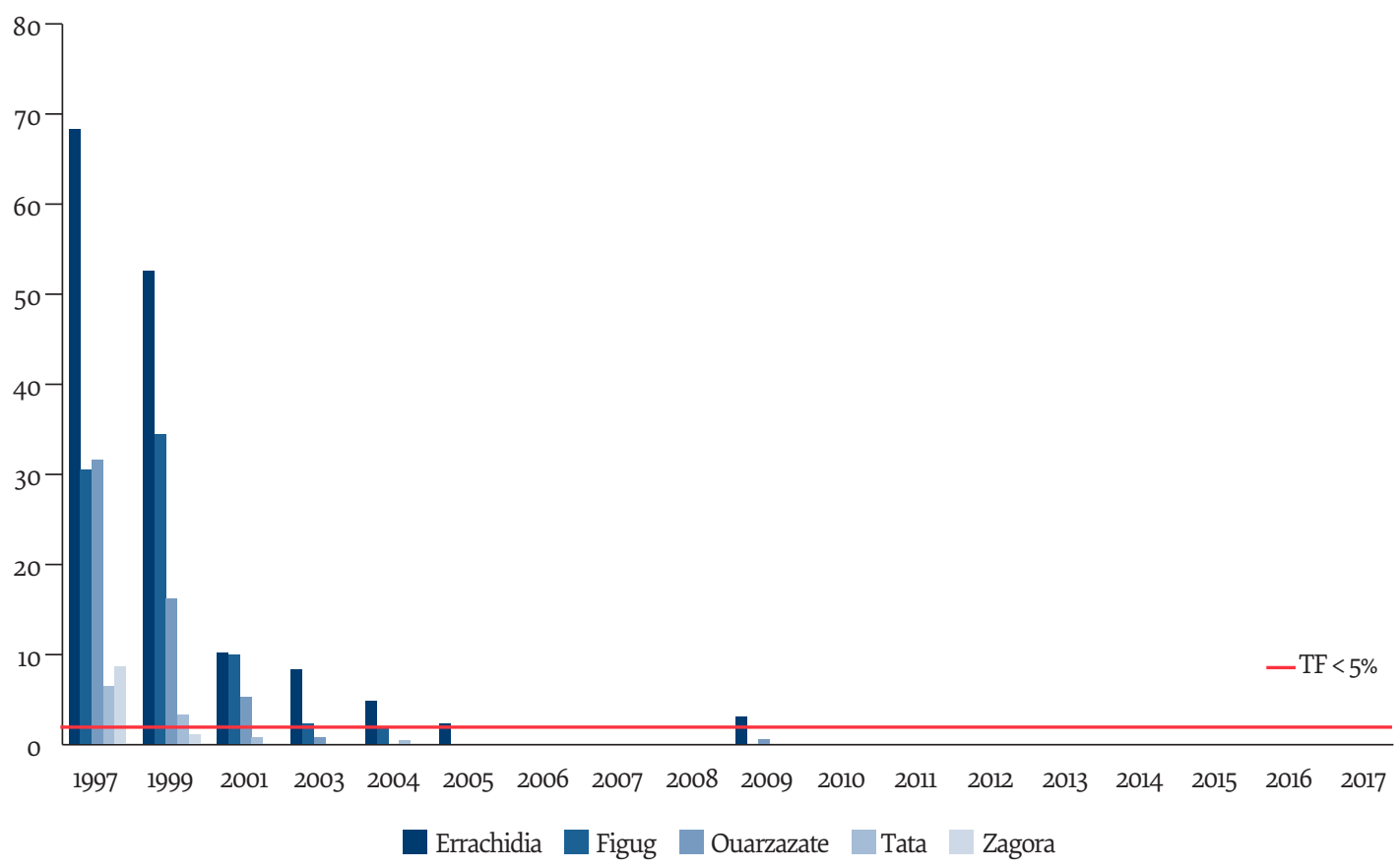




\section{Figure 3 Surgical treatment of trachomatous trichiasis (TT) in the target provinces 1992-2015}

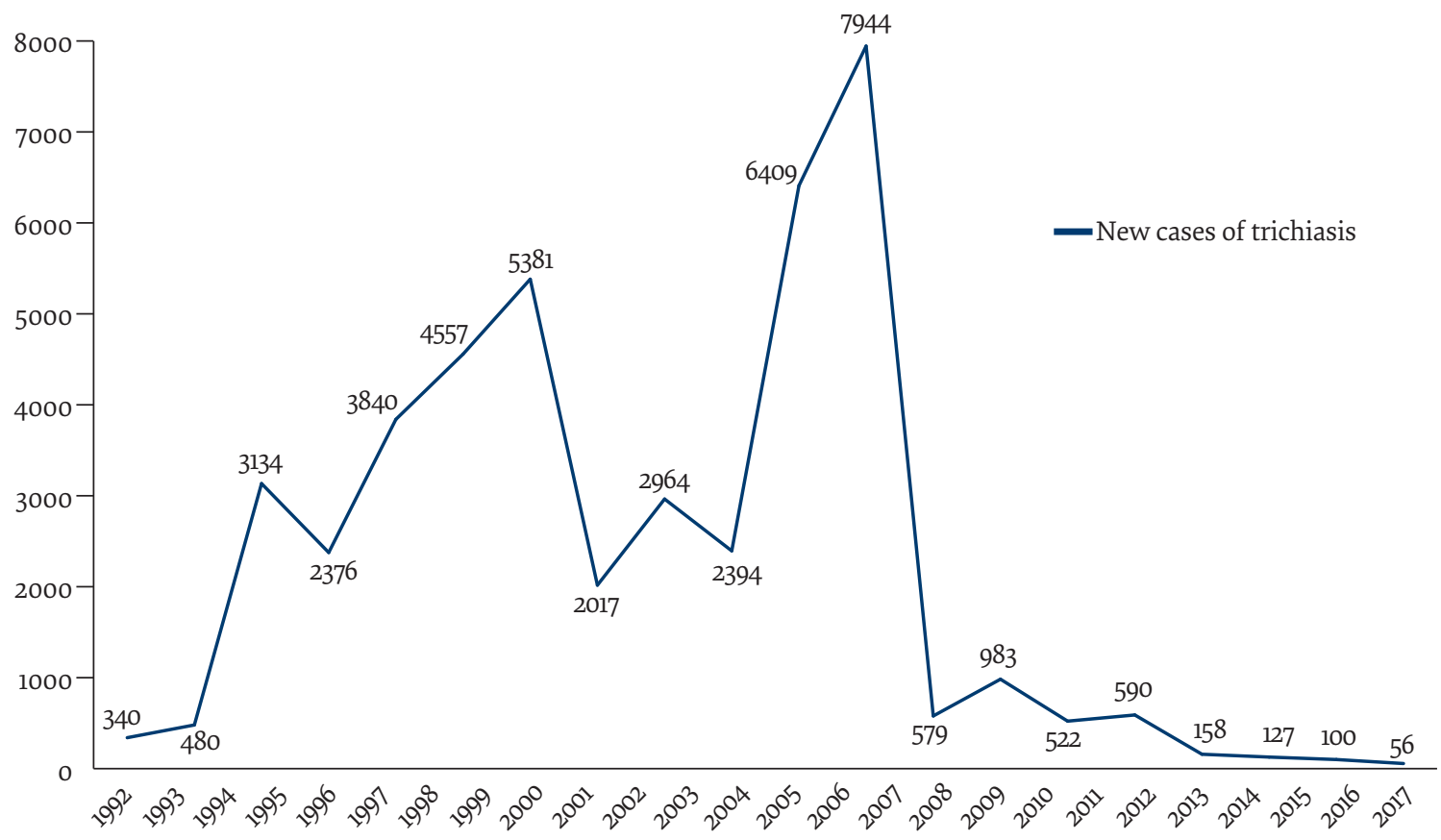

From 1997 to the end of 2005, 35000 people with TT were treated surgically. This reduced the prevalence of TT to less than 0.1 per 1000 in the all-ages population of the targeted provinces. In accordance with WHO recommendations, the programme continued to operate on incident cases of TT (Figure 3).

The distribution of antibiotics was accompanied by education and awareness-raising actions using various methods of communication, including radio, television, print media and movies about the disease, its risk factors and its consequences. Schools, health facilities, educational and social centers and mosques were also used to organize communication activities. Approximately 1.3 million people benefited from these activities each year. Physical actions to improve personal and collective hygiene were also undertaken, including: 1) organizing cleanliness campaigns, such as measures

Figure 4 Evolution of the rate of clean face (\%) in children aged 1-9 years

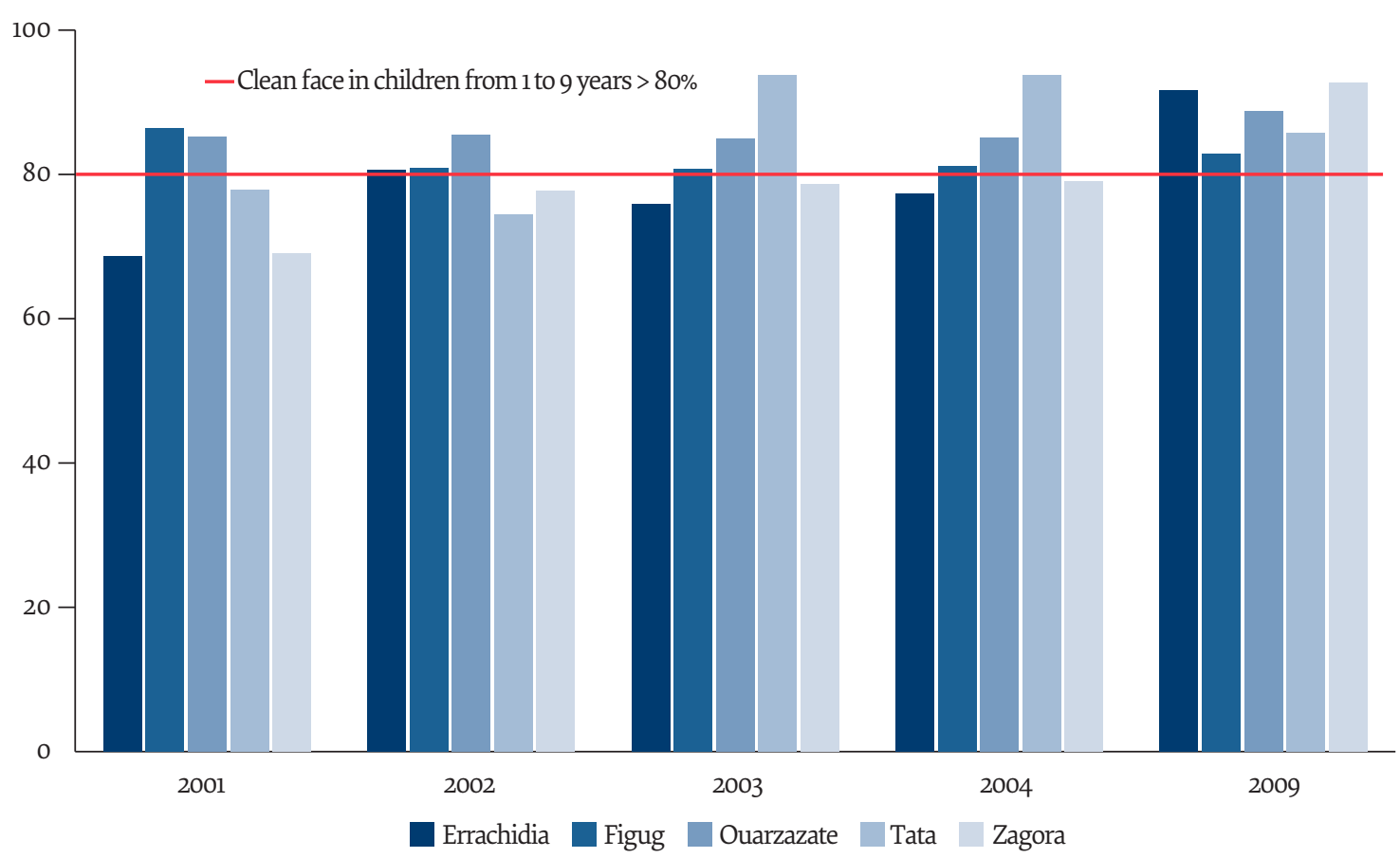


to fight flies, and demonstrations of hygienic disposal of human waste; 2) constructing latrines in schools and mosques; and 3) drilling wells and constructing water towers to provide water to mosques, schools and communities. The prevalence surveys conducted by the programme provided an opportunity to assess the cleanliness of the face and the conditions of collective hygiene. WHO's definition of "clean face" was used in the various prevalence and hygiene assessment surveys (Figure 4).

By the end of 2005, Morocco had reached the elimination prevalence targets and initiated the establishment of epidemiological surveillance work.

The epidemiological surveillance system was developed by the Moroccan programme with support from WHO, ITI and the International Agency for the Prevention of Blindness, Italy. It allowed control of the determinants of trachomatous disease and rested on existing structures in the national healthcare system (Provincial Epidemiology Cells, Regional Epidemiology Observatories and the Epidemiological Surveillance Service). The trachoma epidemiological surveillance system was established at the level of the target provinces to help track trends in trachoma, to generate decisions and facilitate action at the local level. It incorporated three methods, as follows: 1) sentinel surveillance of TF. Each year, children aged 1-9 years attending schools or primary healthcare centres were routinely screened. In each TF case, a contact investigation was commenced in the family and in the village. 2) The epidemiological surveillance of TT. This is based on a strategy called "exhaustive screening of TT" for the whole population (door to door). 3) Special investigations and epidemiological studies (24).

In 2009, the Ministry of Health carried out representative surveys in order to assess the epidemiological situation of trachoma at the level of the most disadvantaged communities in the target provinces, to measure some indicators related to behaviour change and environmental improvement and to evaluate the epidemiological surveillance system for trachoma.

In 2010, the results of these surveys were validated by a committee of national and international experts in Rabat. They reached two important conclusions: 1) no cases of TI were observed in children aged $1-9$ years in all provinces; and 2) comparative analysis of cross-sectional data with those of the epidemiological surveillance system for trachoma showed that the latter was supplying critical information to monitor trachoma (25).

In2015,WHO'sStrategicand TechnicalAdvisory Group on Neglected Tropical Diseases endorsed standardized processes for confirming and acknowledging success for all neglected tropical diseases targeted for eradication, elimination of transmission, or elimination as a public health problem. The process for diseases targeted for elimination as a public health problem was defined as "validation" (26).

Elimination of trachoma as a public health problem is defined as: 1) a prevalence of TT "unknown to the health system" of $<1$ case per 1000 all-ages population (or $<0.2 \%$ in $\geq 15$-year-olds); and 2 ) a prevalence of $\mathrm{TF}$ in children aged $1-9$ years of $<5 \%$, in each formerly endemic district, and a system to identify and manage incident cases of TT (27).

Establishing that the TT and TF prevalence thresholds have been met in a district is a two-step process. First, following a period of implementation of interventions against trachoma, and at least 6 months after the final planned round of antibiotic mass drug administration has been completed, an impact survey is undertaken. If the TF prevalence threshold has been met, the district enters a 2-year period of pre-validation surveillance, during which time antibiotic mass drug administration should not be implemented. Second, at the conclusion of that 2-year period, a pre-validation surveillance survey should be undertaken $(28,29)$.

In perfect agreement with WHO criteria for validation of trachoma's elimination as a public health problem, Morocco presented a dossier documenting the achievement of elimination targets. The epidemiological situation at the end of 2016 was characterized by:

- Prevalence of TT $\leq 1 / 1000$ in the all-ages population.

- Prevalence of TF $0.92 \%$ in children aged $1-9$ years.

The dossier presented information to support the current epidemiological situation of trachoma in the country and described the systems for identifying and managing patients with TT. Based on the evidence provided in the dossier and the recommendation of an ad-hoc dossier review group, WHO concluded that Morocco had eliminated trachoma as a public health problem. This great achievement was officially announced by WHO in November $2016(30,31)$.

\section{Results and conclusions}

The lessons to be learned from the Moroccan programme to fight trachoma include the following elements that were felt locally to be critical to success (32):

- Political engagement

- Integration of trachoma control in primary health care

- Implementation of all components of the SAFE strategy

- Adoption of evaluation as a fundamental component of monitoring and planning

- Decentralization of planning, monitoring and evaluation

- Communication to the general public on the progress of the fight against trachoma (including, for example, field visits by media professionals).

Morocco would be happy to advise other countries engaged in the fight against trachoma.

Funding: None.

Competing interests: None declared. 


\section{Élimination du trachome au Maroc : une revue historique}

\section{Résumé}

Depuis les années 1950, le Royaume du Maroc est l'un des pionniers de la lutte contre le trachome. Cette maladie a complètement disparu de la majeure partie de son territoire national, mais elle demeurait endémique dans certaines poches, représentant un risque pour la santé, en particulier pour les enfants et les femmes.

Aujourd'hui, grâce à des années d'efforts conjoints, le Maroc se trouve à l'avant-scène de la lutte mondiale contre le trachome. À travers son expérience, le pays a démontré l'efficacité et la pertinence de la stratégie « CHANCE », programme à grande échelle conçu pour s'attaquer au trachome et à ses complications. La mise en œuvre de cette stratégie est complexe. Elle nécessite la participation conjointe d'un ensemble d'acteurs se consacrant à des activités spécifiques, qu'il s'agisse d'activités de prise en charge médico-chirurgicale visant à mettre en place un projet physique de développement local ou d'activités d'information et de sensibilisation.

Pour réussir à éliminer durablement le trachome cécitant, la solution a consisté non seulement à étendre la distribution de médicaments à toute la zone du projet pendant plusieurs années afin de réduire considérablement le réservoir de transmission interhumaine, mais également à assurer la permanence de cette distribution. De plus, les services qui assurent une chirurgie palpébrale de qualité et surtout des campagnes régulières de traitement par antibiotiques, ainsi que des campagnes d'éducation sanitaire et la promotion de l'hygiène personnelle et collective, ont généré des changements durables dans l'environnement de vie des populations qui en bénéficient.

$$
\begin{aligned}
& \text { القضاء على التراكوما في المغرب: استعر اض تاريخي }
\end{aligned}
$$

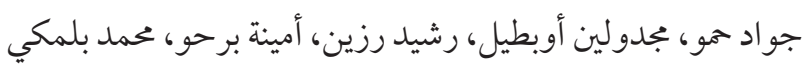

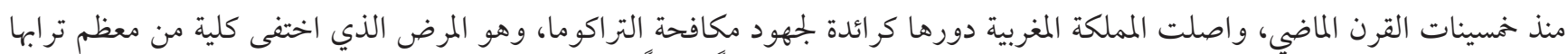

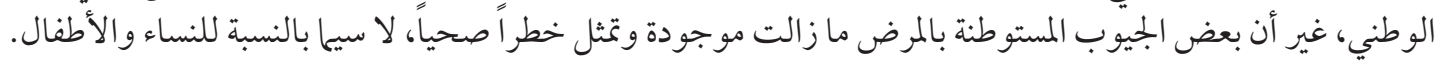

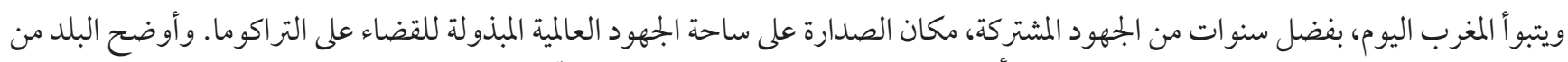

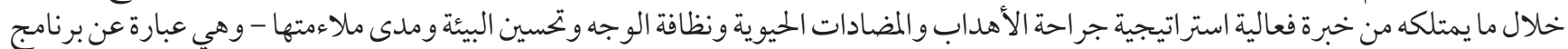

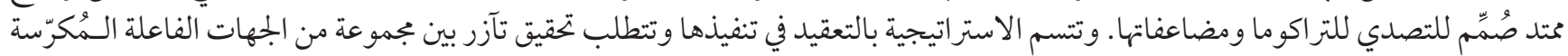

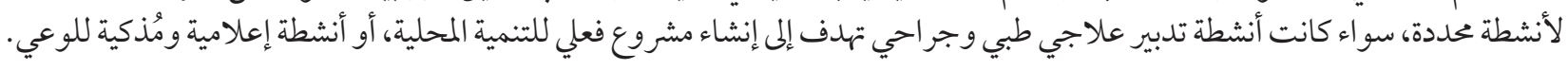

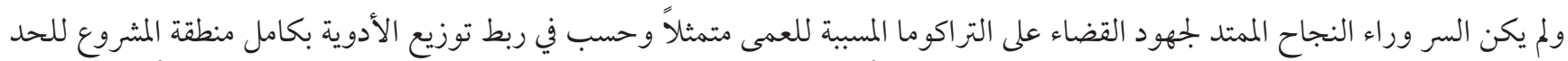

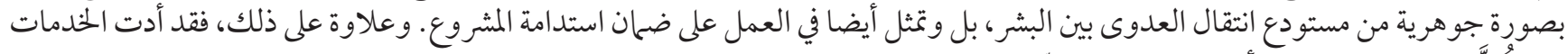

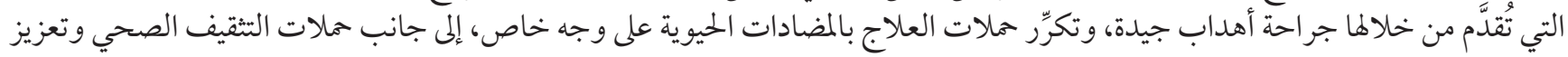

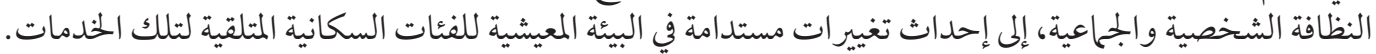

\section{References}

1. Hadfield J, Harris SR, Seth-Smith HMB, Parmar S, Andersson P, Giffard PM, et al. Comprehensive global genome dynamics of Chlamydia trachomatis show ancient diversification followed by contemporary mixing and recent lineage expansion. Genome Res. 2017 Jul;27(7):1220-1229. https://doi.org/10.1101/gr.212647.116

2. Gambhir M, Basáñez MG, Burton MJ, Solomon AW, Bailey RL, Holland MJ, et al. The development of an age-structured model for trachoma transmission dynamics, pathogenesis and control. PLoS Negl Trop Dis. 2009 Jun 16;3(6):e462. https://doi. org/10.1371/journal.pntd.0000462.

3. Palmer SL, Winskell K, Patterson AE, Boubacar K, Ibrahim F, Namata I, et al. "A living death": a qualitative assessment of quality of life among women with trichiasis in rural Niger. Int Health. 2014 Dec;6(4):291-7. https://doi.org/10.1093/inthealth/ihuo54

4. Résolution WHA51.11. Élimination mondiale du trachome cécitant. In : Cinquante et Unième Assemblée mondiale la Santé, Genève, 11-16 mai 1998. Résolutions et décisions, annexes (WHA51/1998/REC/1). Genève : Organisation mondiale de la Santé ; 1998.

5. Bourne RR, Stevens GA, White RA, Smith JL, Flaxman SR, Price H, et al. Causes of vision loss worldwide, 1990-2010: a systematic analysis. Lancet Glob Health. 2013;1(6): e339-49. https://doi.org/10.1016/S2214-109X (13)70113-X. PubMed PMID: 25104599.

6. Weekly epidemiological record Relevé épidémiologique hebdomadaire 29 JUNE 2018, 93th YEAR / 29 JUIN 2018, 93 e année - No 26, 2018, 93, 369-380 (http://www.who.int/wer). 
7. Flueckiger RM, Courtright P, Abdala M, Abdou A, Abdulnafea Z, Al-Khatib T, et al. The global burden of trichiasis in 2016. bioRxiv. 2018;348995.

8. Delanoë E. (Mazagan), Historique de la lutte antitrachomateuse au Maroc de 1913 à nos jours, Maroc Médical n³29, 1952.

9. Pages R. (Rabat), Conjonctivites folliculaires et trachome, Maroc Médical n³48, 1954.

10. Nizetic B. Sur les aspects « Santé Publique » des problèmes de la vision et des maladies oculaires au Maroc, (essai d'une approche globale devant servir comme base à l'établissement d'un plan d'ensemble dans le domaine de l'ophtalmologie), mars 1970

11. Reinhards J. Rapport sur une visite au Maroc 4-26 février 1968, Fonctionnaire médical pour les maladies oculaires transmissibles, Maroc 0509 PNUD (AT) 250-53.

12. Kupka K, Nizetic B, Reinhards J. Sampling studies on the epidemiology and control of trachoma in southern Morocco. Bull World Health Organ. 1968;39(4):547-566

13. Reinhards J, Weber A, Nizetic B, Kupka K, Maxwell-Lyons F. Studies in the epidemiology and control of seasonal conjunctivitis and trachoma in southern Morocco. Bull World Health Organ. 1968;39(4):497-545

14. Thylefors BI. Contrôle mondial du trachome : passé présent et futur. Rev.inter.trach et de pathologie oculaire tropicale et subtropicale et de santé publique.1995:10-20

15. Ponghis G. Quelques observations sur le role de la mouche dans la transmission des conjonctivites saisonniares dans le sud-marocain. Bull. Org. Mond. Santé 1957

16. Circulaire du Ministère de la Santé-Royaume du Maroc, $N^{\circ}: 1613 / \mathrm{DE} / 32$ du 27 juillet 1994 Lutte contre les ophtalmies transmissibles en milieu non scolaire.

17. Circulaire du Ministère de la Santé-Royaume du Maroc, $N^{\circ} 333 / \mathrm{DP} / 11 / \mathrm{DE} / 32$ du 19 janvier 1995 Lutte contre les ophtalmies transmissibles en milieu scolaire.

18. Negrel AD, Khazraj YC, Akalay O. Le trachome dans la province de Ouarzazate, Maroc. Bull World Health Organ. 1992;70(4):451456

19. Chami Khazraji Y, Akalay O, Négrel AD. Prévalence et causes de la cécité et de la baisse de vision au Royaume du Maroc, Résultats de l'enquête nationale sur les causes de la prévalence des déficiences visuelles, Rapport final, 1992, Bulletin épidémiologique $\mathrm{n}^{\circ} 5$ du premier trimestre 1992.

20. Thylefors B, Dawson CR, Jones BR, West SK, Taylor HR. A simple system for the assessment of trachoma and its complications. Bull World Health Organ. 1987;65(4):477-483.

21. Chami Khazraji Y, Négrel AD, Ottmani S. Prévalence et gravité du trachome dans le provinces de Ouarzazate (Zagora), Tata, Figuig et Errachidia, Résultats des enquêtes provinciales sur la prévalence du trachome, Rapport final, 1993, Rapport du Programme National de Lutte contre la Cécité, non publié.

22. Résolution WHA51.11. Élimination mondiale du trachome cécitant. In : Cinquante et Unième Assemblée mondiale de la Santé,Genève, 11-16 mai 1998. Résolutions et décisions, annexes (WHA51/1998/REC/1). Genève : Organisation mondiale de la Santé ; 1998.

23. ITI supported trachoma elimination in Morocco from 1995 to 2005. (http://www.trachoma.org/where-we-work/morocco).

24. Hammou J, Mariotti S, Jabr I, Chaouki N. Système de Surveillance Epidémiologique du trachoma (http://associationdesmedecins.ma/wp-content/uploads/2013/12/Guide-de-Surveillance-Epidemiologique-du-Trachome-Cecitant.pdf).

25. Hammou J. Etude communautaire sur le trachome cécitant chez les communautés les plus désavantagées au Maroc. Journal de la Société Marocaine d'Ophtalmologie, nº22-septembre 2013.

26. Generic framework for control, elimination and eradication of neglected tropical diseases. Genève: Organisation mondiale de la Santé; 2016.

27. Report of the 2nd global scientific meeting on trachoma, Geneva, 25-27 August, 2003. Genève: Organisation mondiale de la Santé; 2003.

28. WHO Strategic and Technical Advisory Group on Neglected Tropical Diseases. Technical consultation on trachoma surveillance 11-12 September 2014, Task Force for Global Health, Decatur, USA. Genève : Organisation mondiale de la Santé ; 2015.

29. Validation de l'élimination du trachome en tant que problème de santé publique (WHO/HTM/ NTD/2016.8). Genève: Organisation de la Santé ; 2016.

30. Le Maroc élimine le trachome, la principale cause infectieuse de cécité. Cairo: WHO Regional Office for the Eastern Mediterranean; 2016 (http://www.emro.who.int/fr/media/actualites/morocco-eliminates-trachoma-the-leading-infectious-cause-of-blindness.html)

31. Hammou J, El Ajaroumi H, Hasbi H, Nakhlaoui A, Hmadna A, El Maaroufi A. In Morocco, the elimination of trachoma as a public health problem becomes a reality (Published Online January 11, 2017). Lancet Global Health 2017;5(3):Pe250-e251 https://doi. org/10.1016/S2214-109X(17)30023-2

32. Chami Y, Hammou J, Mahjour J. Leçons à tirer du programme marocain de lutte contre le trachome. Revue de Santé Oculaire Communautaire 2005;2(1):21 